\title{
ORIGINALISM, RULE OF LAW AND HUMAN RIGHTS
}

\author{
Prof. PhD. Roberto Parra DORANTES, \\ Universidad del Caribe (Cancún), \\ MEXICO, \\ Email: rdparra@ucaribe.edu.mx
}

\begin{abstract}
In this paper I shall defend a moderate version of original meaning originalism in constitutional interpretation. First, I will explain some relevant distinctions and qualifications related to originalism and to the specific version of the theory of constitutional interpretation which I will present here. Next, I will briefly compare this version of originalism with the view traditionally regarded as originalism's natural opponent, the doctrine of the living Constitution, and I will argue that these two views are in fact compatible with each other once certain reasonable qualifications have been made to both of them. I shall then offer arguments in favor of the version of originalism presented here, which mainly have to do with the relation between a democratic system under a written constitution and the concepts of the rule of law and human rights. Finally, I will defend this version of originalism against views that hold that, in certain constitutional cases, once the original meaning of the Constitution, so to speak, "runs out", non-originalist methods should be employed to reach a legal solution.
\end{abstract}

Keywords: originalism; constitutional interpretation; rule of law; human rights;

\section{INTRODUCTION}

In this paper I shall defend a moderate version of original meaning originalism in constitutional interpretation. First, I will explain some relevant distinctions and qualifications related to originalism and to the specific version of the theory of constitutional interpretation which I will present here. Next, I will briefly compare this version of originalism with the view traditionally regarded as originalism's natural opponent, the doctrine of the living Constitution, and I will argue that these two views are in fact compatible with each other once certain reasonable qualifications have been made to both of them. I shall then offer arguments in favor of the version of originalism presented here, which mainly have to do with the relation between a democratic system under a written constitution and the concepts of the rule of law and human rights. Finally, I will defend this version of originalism against views that hold that, in certain constitutional cases, once the original meaning of the Constitution, so to speak, "runs out", non-originalist methods should be employed to reach a legal solution.

Perhaps I should warn that some parts of my proposal could at first glance appear to be radical and revisionist. But calling a view 'revisionist' is not necessarily attributing a flaw to such a view. More importantly, when present practices merit improvements, anything less than revisionism in a theory about such practices is likely to help prevent such improvements. On the other hand, I believe that the view I will defend here, once clarified, turns out to be less radical that what it may appear to be at the beginning.. 


\section{ORIGINALISM: SOME DISTINCTIONS AND QUALIFICATIONS}

Originalism can be characterized as a group of theories of constitutional interpretation which distinctively hold the following two claims jointly: first, the meaning of a Constitution is fixed at the moment that Constitution acquires validity, i.e. at the moment it is ratified; second, the meaning of the constitutional text has a predominant importance when deciding constitutional cases. This is just a general characterization of originalism; it would be a mistake to assume that the different originalist theories share much more than what these two claims state. The general idea underlying originalism is that a constitutional text represents the core of constitutional law within most modern legal systems, and should therefore be considered as the main guide to the resolution of disputes concerning constitutional law.

An important distinction between to different kinds of originalism has been frequently made; it is the distinction between 'original intention originalism' and 'original meaning originalism'. (Barnett, p. 89) According to those who defend original intention originalism, the meaning of the Constitution must be sought in the intentions and purposes that the people in charge of writing, approving, and ratifying the constitutional text had in mind. This kind of theory has been rightly criticized by some constitutional theorists, for example Paul Brest (Brest, pp. 229 ff.), as being impracticable: if it is often difficult to know with some degree of certainty the intention of any person while performing any action even when that person is available to answer our questions, it seems practically impossible to determine 'the' intention that a collective group composed by members with heterogeneous backgrounds and interests had many years ago in the course of creating and conferring validity to each one of the clauses of the Constitution. Presumably, these people had different conceptions of what they were doing, and probably even incompatible purposes and objectives while doing what they did. Furthermore, it seems there is a large measure of probability that the intentions of those who drafted the constitutional text did not exactly match the intentions of those who approved it or ratified it. Because of these and other similar objections raised against this view, original intention originalism has declined in popularity in recent years.

Original meaning originalism, however, eludes these criticisms by attaching predominant importance, in the context of constitutional interpretation, not to the intentions or purposes that the framers might have had, but to the constitutional text itself, which, after all, was what the framers approved and ratified, and therefore what is still binding in the present. According to this view, then, the meaning of the Constitution must be extracted from the ordinary meaning that at the time of the ratifying the words within constitutional provisions had. This ordinary or 'plain' meaning is understood here as what a competent speaker of English (or any language in which a given constitution is written) at that time would have understood these words to mean.

Another relevant distinction between originalist views, and one which can be applied to both versions of originalism just described, is the one between strict originalism and moderate originalism (Brest, pp. 222 ff.). The difference between these has been characterized as a difference in attitude regarding the level of precision with which the object of interpretation (in the case of original intention originalism, the intentions of the drafters, and in the case of original meaning originalism, the constitutional text) must be related to a particular case in order to be correctly applied to it.

The difference between strict originalism and moderate originalism, although important, is, so to speak, only a matter of degree, and therefore the limits between these two kinds of originalism are diffuse and more comparative than qualitative. Strict originalism aims for a high level of precision in the correspondence between the interpreted meaning of 
constitutional provisions and the situations to which those provisions should be applied. Moderate originalism, in turn, by being willing to settle for a lesser degree of exactitude in this correspondence, becomes capable of taking into account, during constitutional interpretation, facts concerning the context of the situations and the imprecision (such as vagueness and ambiguity) which naturally accompanies ordinary language.

The defect of strict originalism, as compared with moderate originalism, is that the level of precision that this kind of theory demands for the application of the meaning of constitutional norms to concrete cases is in many cases simply impossible to obtain. Legal (and constitutional) interpretation will unavoidably have to deal with problems of indetermination in language. This point can perhaps be made clearer if we take into account the ideas of Hans Kelsen about the nature of legal interpretation. According to Kelsen (pp. $348 \mathrm{ff}$.), the natural indetermination inherent to general words - the very quality which makes it possible for them to be applied to many different concrete objects and situations - causes any written law to correlate not just one specific set of legal consequences to a certain situation or set of facts, but always at least several sets of such consequences, between which the legal interpreter in charge of applying the norm must choose.

Kelsen explains that a written law, regardless of the care and precision with which it is drafted, can therefore only establish a 'frame' of acceptable interpretations, all legally valid, between which the judge must choose (ibid., p. 351); however, in Kelsen's opinion, once the law has been interpreted and the frame which includes all the possible legal solutions has been identified, the judge is, from the point of view of the law, at liberty to select any of those interpretations that fit in that frame. Of course, in order to correctly identify such a frame, it might be possible that the judge will need to interpret simultaneously many legal provisions, including legal norms from different levels of abstraction, perhaps also including very general constitutional norms stated in the form of moral principles. Kelsen's account of legal interpretation does not exclude these considerations. But once the frame has been correctly identified, he thinks, from the point of view of the law there is no reason to give preference to any of the solutions contained in that frame. He writes: "The law to be applied constitutes only a frame within which several applications are possible, whereby every act is legal that stays within the frame" (ibid.).

The urge commonly felt by legal interpreters to find the only correct legal solution is then, from this perspective, mistaken; it is sufficient that the solution selected by the judge fits in the frame established by the law for it to be as legally valid as it can be. In practice, there will often be other sorts of considerations a judge will take into account to reach a decision, for example an appeal to alleged objective moral rules not contained in the legal system; there could perhaps even be an objective moral obligation for the judge to prefer one among all the possible legal solutions (or even to prefer a solution which is not included in that frame), but there is no legal obligation for the judge, while applying the law to a particular case, except to select a solution for it that fits the legal frame of the norm and apply it.

Kelsen's ideas about legal interpretation as the identification of a frame are important for constitutional interpretation not only because they help us understand that strict originalism requires a level of precision in the laws and the Constitution which is impossible to obtain through ordinary language. They are also helpful, as we shall see later, for understanding the limits that constrain a judge applying the law insofar as the judge is actually applying the law and not doing something else. 


\section{A NORMATIVE VERSION OF ORIGINALISM}

The theory of original interpretation which I intend to defend here is explicitly normative and not descriptive. This point merits some clarification. A descriptive theory has the objective of accurately representing the features of the object of interpretation such as that object actually is. A normative theory, in contrast, attempts to justify a position according to which an object should be conceived in a certain way when seen in the light of a certain normative standard, usually implying by this that, in accordance with that normative standard, only certain sorts of attitudes or actions are justified or authorized in response to certain situations regarding the object of the theory.

In the context of constitutional interpretation theories, a claim is commonly made to the effect that a successful theory of constitutional interpretation must be at the same time normative and descriptive (e.g. Fallon, pp. 1232-1234). The reason offered in support of this claim is that, according to those who hold this view, a normative theory which does not contain descriptive elements to help it correctly identify its object (for example, a national Constitution) cannot even be correctly said to be a theory about that object.

This reasoning is wrong. Although it is true that a normative theory must take into proper account the features of its object (so that it constitutes a theory about that object in the first place), this does not entail that a normative theory must include descriptive elements. It might well be possible that the constitutional interpreter will need two kinds of theories, one normative and one descriptive, to adequately perform his or her job. However, this does not lend any support to the claim that a constitutional theory should be a mixture of both normative and descriptive elements.

Once having clarified that the version of originalism I shall defend here is normative and not descriptive, we are in a position to see how many of the objections that have been frequently directed towards originalism in general do not touch the version of originalism proposed here, since these criticisms are applicable to originalism, if at all, only as a descriptive theory.

Thus, for example, Brest regards as a serious defect of moderate originalism the fact that "contrary to the moderate originalist's faith, the text and original understanding [of the Constitution] have contributed little to the development of many doctrines she accepts as legitimate." (Brest, p. 231) And Fallon, while discussing what he calls the problem of commensurability in constitutional theory (the problem about how the constitutional interpreter should combine the weight of the different kinds of arguments commonly utilized in the context of constitutional interpretation) argues that originalism "fails spectacularly" as a descriptive theory because it is not capable of accommodating the importance which is given to those arguments used in constitutional interpretation which are not derived from the constitutional text or the original understanding. (Fallon, p. 1213) Needless to say, these criticisms could only affect originalism conceived as a descriptive theory, and not as normative theory.

Having presented the main characteristics of the version of originalism that I shall defend, perhaps it is useful, in order to understand it better, to compare it with one of the theories traditionally regarded as the opposite of originalism, the doctrine of the living Constitution. 


\section{ORIGINALISM AND THE LIVING CONSTITUTION}

Originalism is frequently contrasted with what has been called the doctrine of the living Constitution, according to which, in rough terms, the Constitution is a living organism which adapts itself to the changing circumstances in society. In less metaphorical terms, this means that, according to this view, the meaning of the language of the Constitution does not remain fixed through time, and is therefore able to be reinterpreted in different ways so as to provide solutions for controversies that the framers did not and could have not been able to foresee. It is easy to caricaturize this idea. The late US Supreme Court Justice Antonin Scalia, for example, has said that the argument in favor of this doctrine goes like this: "the [American] Constitution is over two hundred years old and societies change. It has to change with society, like a living organism, or it will become brittle and break. But you would have to be an idiot to believe that. The Constitution is not a living organism; it is a legal document. It says something and doesn't say other things." (cited by Epps, p. 25)

I would like to argue that, once some reasonable qualifications have been made on both sides, originalism is perfectly compatible with the idea of a living Constitution in a way that preserves a large part of the appeal of both views.

To understand this perhaps it is useful to make a distinction, originally made by John Stuart Mill, between the connotation and denotation of words (Mill, p. 31-32). According to this distinction, the connotation of a term consists of a certain set of features that an object must possess in order to be rightly considered a member of the class designated by said term. The denotation of a word, in turn, consists in the set of all the objects that possess those features and therefore are designated by that word. For example, the usual connotation of the English word 'vehicle' could be described as, say, the feature of being an object the function of which is to transport people or other objects from one place to another. The denotation of 'vehicle' is constituted by all the objects that have this feature, including automobiles, horse carriages, trains, airplanes, etc.

It is well known that the meaning of words is susceptible to change from time to time; the word 'gay', for example, previously used to signify roughly the same as 'joyful', in the last decades has acquired the meaning of 'homosexual', so that hardly anyone now would use it with its original meaning. In such a case, what has changed is the connotation of the term. However, and this is a much more interesting case for our present purposes, it is also possible and common for the connotation of a term to remain constant while its denotation changes over time. In the example of 'vehicle', this would happen every time a new type of vehicle was invented, for instance, a personal spaceship. In this case it could be said that, in a way, part of the meaning of the term (its denotation) has changed, even though it is clear that an essential part of its original meaning (its connotation) remains unchanged. The same can happen with many other kinds of words, not only with those whose denotation depends on scientific and technological advancements. For example, it is obvious that the set of objects correctly designated by the word 'fashionable' can change from year to year (or even from season to season), while it is plausible to think that the connotation of this word has remained more or less stable through generations.

For the purposes of legal interpretation in general, and even more within the context of constitutional law, where the legal interpreter is bound to having to deal with texts written a long time ago, the distinction between connotation and denotation seems to be very helpful, since it allows us to understand how, even if the meaning (i.e., the connotation) of the words included in the constitutional provisions is fixed at the moment that the Constitution acquires validity (as the originalist holds), it is perfectly natural for its denotation to change over time, 
in a way that could be rightly considered as an adaptation to new circumstances. I believe that the long dispute about the meaning of the phrase "cruel and unusual punishment" in the Constitution of the United States, in the context of the discussion about the constitutionality of the death penalty, could come nearer to a solution acceptable for both originalists and nonoriginalists if the importance of the distinction under discussion was understood more clearly. I think practically anyone (both in the eighteenth century and in current times) would agree that a 'cruel punishment' is just a punishment which inflicts a large amount of suffering without an adequate justification. Nonetheless, it is perfectly conceivable (and to some extent empirically verifiable) that an average reasonable citizen two hundred years ago would think that the death penalty is not a cruel punishment, while perhaps for an average reasonable citizen from our times the death penalty probably would in fact constitute a cruel punishment. This kind of view would allow reconciling the originalist ideal of interpreting the Constitution faithfully and according to how it was understood at the moment of the ratification, with the living constitutionalist attractive idea of having a Constitution that adapts itself to, as the US Supreme Court expressed in the Trop v. Dulles decision, the "evolving standards of decency that mark the progress of a maturing society" (cited by Van den Haag and Conrad, p. 166).

In the next section I turn to the arguments in support of the version of originalism proposed in this paper.

\section{ORIGINALISM AND THE RULE OF LAW}

The main argument in support of the version of originalism here defended is misleadingly simple; its power depends on recognizing the value of a written constitution for a democratic society. A written constitution makes it possible for the basic rules of the functioning of the government, as well as the limits to the exercise of government action, to be known by everyone that should abide by the legal system, including state authorities. A valid written constitution is a special public agreement in constant renovation between the government and the people, in which every clause of the agreement can be known by the parties bound by it. Implicit in the notion of a written constitution of a democratic regime is the idea that the government must respect in its actions the limits imposed by the Constitution, and that the people, in exchange for that, grants legitimacy to such Constitution and government. The version of originalism defended here simply states that the government, and in particular the judicial branch, must always base its actions in the content of the Constitution, and that, when the Constitution is written, the only way of doing this is basing its decisions on the constitutional text. Whenever state authorities (including judges) guide their institutional actions by anything different to the written content of the Constitution, both the Constitution and the government lose a certain measure of legitimacy, for reasons that will be explained later in this section, even if the authorities act in a way which is in some sense even better than what the Constitution requires.

In a constitutional framework such as the one from the United States, partly because of the importance that is given there to the precedent system, this important feature of written constitutions sometimes runs the risk of passing unnoticed. In contrast with other legal systems, for instance those derived from a Roman tradition, within American law it is perfectly common for a judicial decision to routinely become a general norm for future similar cases. The US Supreme Court itself functions in that way, and so its decisions in specific cases are binding for similar cases that may arise in the future. In constitutional cases, the decisions reached by the Supreme Court through a certain interpretation of the 
Constitution become, in a sense, constitutional law. Still, this does not mean that the justices of the US Supreme Court are in any way authorized to create the norms of the constitutional system more generally. After all, the justices of the Supreme Court are the authorities within that system only in virtue of the rules stated by the Constitution.

Antonin Scalia complains about this tendency to generalize the American common law system to the constitutional realm: "the ascendant school of constitutional interpretation affirms the existence of what is called The Living Constitution, a body of law that (unlike normal statutes) grows and changes from age to age, in order to meet the needs of a changing society. And it is the judges who determine those needs and 'find' that changing law. Seems familiar, doesn't it? Yes, it is the common law returned, but infinitely more powerful than what the old common law ever pretended to be, for now it trumps even the statutes of democratic legislatures." (Scalia, p. 38) Scalia notes also how, if one attends a class on American constitutional law, or examines a textbook of American constitutional law, or pays attention to how briefs are written in constitutional cases, one will hardly ever find any discussion revolving around the text of the relevant constitutional provision, or the meaning of that text. The starting point, he says, is always previous cases decided by the Supreme Court, and new cases are expected to be solved in accordance with the principles expressed in those past decisions, "with no regard for how far that logic, thus extended, has distanced us from the original text and understanding" (ibid., p. 39).

I think Scalia raises an important issue here. The non-originalist could respond that the distancing from the text and the original understanding of the Constitution are justified, at least in the United States, by the highly-regarded American tradition of common law, and that it is simply a built-in characteristic of the American constitutional system (and a desirable characteristic for that matter) that constitutional precedents, although originally derived from the Constitution, should on the long run distance themselves from it and acquire, for the resolution of future constitutional cases, the same or even more importance than the constitutional text itself. This is a perfectly understandable and coherent view, defended for example by David Strauss (Strauss, 1996). Nevertheless, I believe there are decisive political and moral reasons to reject it. These reasons, which I will discuss presently, have to do with the concept of the rule of law.

According to Joseph Raz, whose arguments I follow on this issue, the rule of law is a political and moral ideal often expressed by the slogan 'government by law and not by men', where 'law' should be understood as a "general, open, and relatively stable law" (Raz, p. 213). The notion of the rule of law in a literal sense is composed, according to this author, by two parts: first, the people must be governed by the law and they must obey it at least generally, and second, the law must be such that the people who it addresses can be successfully guided by it. But the law is capable of guiding a person's behavior (and thus capable of being obeyed by that person) only if "one part of his reason for conforming is his knowledge of the law". (ibid., p. 214) It is impossible for someone who does not know or understand the law to follow it (as opposed to merely acting in conformity with it by chance). Therefore, a prerequisite for the rule of law to be possible is that the law can be known and understood by the people, in such a way that they can guide their actions based on such knowledge and understanding.

Raz derives from the idea of the rule of law three principles which must be followed in order to make the rule of law possible. The first one states: "All laws should be prospective, open, and clear" (ibid., p. 214). With this, he means that laws should not be retroactive, that they should be readily accessible for people governed by them, and that they 
should be capable of being understood by the people. The second principle reads: "Laws should be relatively stable" (ibid.). If laws are constantly changing, this may affect their capability of being known and understood by the people. Finally, the third principle says: "The making of particular laws (particular legal orders) should be guided by open, stable, clear, and general rules." (ibid., p. 215) Here Raz is referring to particular legal decisions by authorities in charge of applying the law to concrete cases. This process and its rules should be as open, stable, and clear as the laws, for otherwise the people will frequently not be able to guide their conduct by the law even if the know it and understand it.

Raz, while discussing these principles, only talks explicitly about laws, but the force of his arguments is the same, or perhaps greater, when applied to constitutional norms: if knowledge of statutory law is fundamental for the rule of law, even more important will it be for the people to know and understand the content of the Constitution, which includes the scope and limits of state authority action and the most fundamental rights that must be respected by the government. It seems clear that if the entire legal system, including its constitutional component, does not abide by these principles, the ability of the citizens to know the law and to understand and predict the acts of the authorities will be seriously compromised.

Moreover, as Raz contends, an essential part of individual freedom and of respect for human dignity depends on the people's ability to plan their activities in accordance with their knowledge of what the law requires them to do or prohibits them from doing. Raz writes: "Observance of the rule of law is necessary if the law is to respect human dignity. Respecting human dignity entails treating humans as persons capable of planning and plotting their future". (ibid., p. 221)

All this leads Raz to conclude that "the rule of law is not merely a moral virtue - it is a necessary condition for the law to be serving directly any purpose at all. [...] Conformity to the rule of law is an inherent value of laws, indeed it is their most important inherent value. It is of the essence of the law to guide behaviour through rules and courts in charge of their application." (ibid.)

These considerations, I believe, overwhelmingly support the conclusion, generalizable to any constitutional framework, that constitutional norms, as much as any other laws, should be clear, stable, and prospective if they are to promote the rule of law in the way that is required by the respect of human rights and freedom. This cannot occur when the constitutional order relies excessively on the system of precedent, where each previous decision potentially changes the meaning of the norms, and where little by little the distancing that Scalia objects to between the constitutional text and the set of criteria effectively utilized to solve constitutional disputes appears and only increases over time.

But these reflections also point to another important universally generalizable conclusion: constitutional provisions that suffer from obscurity in a relatively high degree can also constitute threats to the possibility of rule of law inasmuch as they prevent the people from being able to predict state action and plan their lives accordingly. It is generally accepted that a Constitution should be written in terms with a high level of abstraction so that it is able "to be accommodated to times and events". However, it must be acknowledged that a markedly high degree of abstraction in constitutional language will frequently entail a high degree of obscurity and indeterminacy, and the people that must obey the Constitution (including the authorities), under these circumstances, will not on many occasions be able to base their conduct adequately on their knowledge of the law, as detailed as this knowledge may be. 
Furthermore, when a legal statute (as opposed to the Constitution) is obscure, a judge can make use of certain resources to clarify its meaning. Among these strategies, an important one is that the judge can look up to higher norms within that legal system, for example the Constitution, and decide on that basis between the apparent possible interpretations for the obscure statute. In some cases, whatever the intended meaning of that statute was, it should be interpreted only in a certain way because of the fact that any alternative interpretation is prohibited by hierarchically superior norms, ultimately constitutional norms.

In the constitutional realm this strategy is not open to the interpreter, simply because there is not any higher legal norm. It is understandable, though, that the constitutional judge is often tempted to apply a similar strategy, where the "superior norms" under the light of which the Constitution should be interpreted are supposedly objective moral principles and ideals. I would like to argue that a judge, and especially a constitutional judge, should always resist this temptation. The reason for this is not that the judge, by applying this strategy, will inevitably apply morally wrong principles and values (although this is certainly an open possibility in any such case), but rather that in these cases the judge will simply not be applying the law in his or her decisions, and therefore any decision he or she makes will be in detriment of the rule of law.

Raz supports this view, I believe, when he claims that "the one area where the rule of law excludes all forms of arbitrary power is in the law-applying function of the judiciary where the courts are required to be subject only to the law and to conform to fairly strict procedures." (ibid., p. 219, emphasis added)

\section{ORIGINALISM AND CONSTITUTIONAL CONSTRUCTION}

This leads us, finally, to the topic of constitutional construction, as opposed to constitutional interpretation. Randy Barnett traces this distinction in a helpful way; he says: "interpretation determines the meaning of words. Constitutional construction fills the inevitable gaps created by the vagueness of these words when applied to particular circumstances" (Barnett, p. 102).

According to Barnett, who proposes a version of originalism which is similar in many respects to the one defended in this paper, originalist constitutional interpretation is not always sufficient to decide a constitutional case, for in some cases a judge, after using the originalist method will have not one, but several legal solutions available, all of them permitted by the original meaning of the Constitution. Barnett says: "when interpretation has provided all the guidance it can but more guidance is needed, constitutional interpretation must be supplemented by constitutional construction", and he readily adds, "within the bounds established by original meaning". (ibid., p. 123) I could not agree more with this statement, but I fear that, given the way it is formulated, it may be difficult to understand precisely what it means.

Larry Solum, for example, describes this part of Barnett's proposal saying that, when the original public meaning "runs out", the application of the Constitution must be supplemented by non-originalist methods. (Solum, p. 934) I think there are at least two different ways to understand the expression about original meaning 'running out' in this last sentence, and therefore at least two different ways of interpreting the need to supplement constitutional interpretation with constitutional construction. Recall the idea proposed by Kelsen according to which legal interpretation consists in identifying a frame of valid legal solutions, where the legal interpreter in charge of applying the law has the freedom to choose 
between any of these solutions, being all of them equally valid from the standpoint of the law. According to the first sense of 'original meaning running out', this is exactly what happens once the judge has identified the frame; now he or she must only choose one between the several legal options contained in that frame.

According to the second sense, it could be meant by this expression that there are cases in which the law or the Constitution do not provide a complete frame, either because of the existence of a legal gap or because the content of the law or the Constitution is not clear enough to allow the identification of a frame of legal solutions. I would say I agree with Barnett's position about supplementing the originalist method of interpretation with nonoriginalist constitutional construction only when the expression 'original meaning has run out' is understood in the first sense; but it seems to me that many important authors (perhaps including Barnett) would allow for constitutional construction in cases where the expression is understood also in the second sense, and with this I disagree.

Ronald Dworkin, for instance, recommends what he calls the 'moral reading' of the Constitution (Dworkin, 1996) as a part of his doctrine of 'law as integrity' (Dworkin, 1986). Through these notions, Dworkin explicitly defends the inclusion of moral considerations by the constitutional judge in the process of applying the Constitution to particular cases. However, Dworkin emphasizes that the interpretation of constitutional provisions must be done not only taking into account what is the solution best supported by the best moral justification. There is also a previous condition, what has been labeled a 'threshold' requirement, according to which any valid legal interpretation must 'fit' the legal text.

Dworkin's ideas on this topic underwent several revisions, and it is not always clear what the definitive position of this author is regarding specific problems of constitutional interpretation. However, I would argue that if Dworkin's view can correctly be described as saying that a specific constitutional interpretation can sufficiently meet what he calls the 'fit requirement' by simply not contradicting what the Constitution explicitly states, then I disagree with his position, for I think that for constitutional interpretation to be valid, it must not be merely consistent with the Constitution, but also, and more importantly, it must be substantially based on what the Constitution says. Following Kelsen's expression, I would say that for any constitutional interpretation to be valid in a specific case, it must be possible to identify in the meaning of the constitutional text a frame containing the legally valid solutions.

Once such frame has been (correctly) identified by the judge, I believe Dworkin's proposed moral reading is applicable to help the judge select the best available legal solution. But, based on the considerations previously stated about the relation between the rule of law and constitutional interpretation, it is important to note that when the Constitution is not sufficiently clear about a certain issue, on occasions it may be entirely correct to say that the Constitution simply fails to establish a complete frame of possible legal solutions for that kind of case, and then the constitutional judge lacks any legally valid basis to make a decision.

Other criteria might be used (and are commonly used) to reach a decision for any of these cases. But I would contend that in such cases judges are not applying the law, and that their action as state authorities violates the rule of law and therefore the human rights of the people governed by that constitutional system. 


\section{CONCLUSION}

I have defended a normative, moderate version of originalism according to which there is a possibility that in a constitutional system there will be cases in which there is no correct legal (constitutional) solution. This follows from the consideration that all legal solutions for constitutional cases must be based directly on what the Constitution explicitly states if the system is to promote the rule of law and thereby respect human dignity and human rights. If the constitutional provisions are not sufficiently clear so as to be able to allow the constitutional judge to identify a frame of legal solutions, the judge must be able to recognize that the legal system lacks the legitimate power to solve the case using the law. Judges then may leave it to that country's legislative power to amend this problem; but they can also argue in their opinions in favor of constitutional amendment which clarifies the issue at hand. Obscurity and indeterminacy are, when they reach this point, great defects in the constitutional framework, and the judicial power of a country should be permitted, in order to respect human rights and human dignity, to recognize and address explicitly these problems in a way that does not undermine the rule of law.

\section{BIBLIOGRAPHY:}

[1] Barnett, Randy E.: Restoring the Lost Constitution: The Presumption of Liberty, revised edition, Princeton University Press, 2014.

[2] Brest, Paul: "The Misconceived Quest for the Original Understanding", Boston University Law Review, 60, 1980; pp. 204-238.

[3] Dworkin, Ronald: Law's Empire, The Belnak Press of Harvard University Press, 1986.

[4] Dworkin, Ronald: Freedom's Law: The Moral Reading of the American Constitution, Oxford University Press, 1996.

[5] Epps, Garrett: Wrong and Dangerous: Then Right-Wing Myths about our Constitution, Rowman and Littlefield Publishers, 2012.

[6] Fallon, Richard: “A Constructivist Coherence Theory of Constitutional Interpretation”, Harvard Law Review, 100, 1987; pp. 1189-1286.

[7] Kelsen, Hans: Pure Theory of Law, translation from the second revised and enlarged German edition by Max Knight, University of California Press, 1967.

[8] Mill, John Stuart: A System of Logic, Ratiocinative and Inductive, vol. I, Longmans, Green, Reader and Dyer, eighth edition, 1872.

[9] Raz, Joseph: The Authority of Law: Essays on Law and Morality, Oxford Clarendon Press, 1979.

[10] Scalia, Antonin: A Matter of Interpretation: Federal Courts and the Law, Princeton University Press, 1997.

[11] Solum, Lawrence B.: "District of Columbia v. Heller and Originalism", Northwestern University Law Review, 103, 2009; pp. 923-981.

[12] Strauss, David A.: "Common Law Constitutional Interpretation”, University of Chicago Law Review, 63, 1996; pp. 877-935.

[13] Van den Haag, Ernest, and John Phillips Conrad. The death penalty: A debate. Springer Science \& Business Media, 2013. 